\title{
The Culture of Accountability in Italian Universities: Strengths and Weaknesses
}

\author{
Paolo Ricci, Renato Civitillo \\ University of Sannio, Benevento, Italy
}

\begin{abstract}
This research work aims to highlight social reporting and accountability system in Italian universities. After cases analysis and content analysis, we provide an overview of the state-of-the-art of accountability in academic research and education. In this perspective, a brief analysis of the most relevant literature regarding the topic is finalized to address and to compare Italian experiences of social reporting. Effective accountability systems can indeed turn from tools into goals in public administrations, and in doing so reporting takes on a completely different meaning: it is a contribution to the social added value created by the university, an extra obligation to take towards stakeholders, a further service to engage in to strengthen democracy. The culture of accountability should be introduced and guided mainly by law, with legal requirements about deadlines, tools and goals, and supervised by third-party authorities. Further work is still needed to fully grasp measurement complexities and the potential lying in the evaluation of academic performance - especially with relation to sociality and sustainability - that plays an important role in national and international ranking systems.
\end{abstract}

Keywords: Social reporting, Accountability, University, Non-financial communication

\section{Introduction}

One of the last attempts to reform the organization and management of the Italian university is represented by the law No. 240, 30 December 2010. This law, in the pursue of real and not merely formal change (Watzlawick, Weakland \& Fisch, 1973), it introduced significant changes in how universities work in Italy. We may identify three categories of main changes:

- of identity, which refers to basic aspects of the university system: founding principles and purpose of the system, preeminent mission of universities

- of governance (Angluin \& Scapens, 2000, p. 9; Deem, 2003, p. 242; Stoker, 1998, pp. 17-27), related to governance contemplate, on the other hand, very targeted and specific measures regarding governing bodies, their capacity and the main rules on the basis of their operation and evaluation

- of accountability, which widen the range of instruments aimed at measuring, monitoring and evaluating management: good examples, albeit in different ways, are the introduction on the one hand of financial and capital accounting (Catalano, 2009) and on the other hand of analytical accounting, and the creation of the ethical code (Gray, Owen \& Adams, 1996; Gray, 2002; Messner, 2009; Mulgan, 2000; Pezzani, 2003; Ricci, 2005; Roberts, 2009; Sinclair, 1995.).

Changes affecting the system of accountability, the main goal is therefore increasing the quality and quantity of tools a university can use to measure - and report about - its activities to third parties. However, this means, as we shall see, that the autonomy needed to compete properly comes at a price that is accountability. Greater autonomy and greater accountability can, for example, improve the opportunities for fundraising, clarify the rationale behind fee increases, or improve relations with other bodies or institutions. Here we can also understand the bias the reform implicitly holds towards the current accounting system based solely on commitment - or for obligations - accounting. Leaving aside changes related to the first two types of intervention, although well aware of the vital connections existing among all the measures adopted, we shall focus on accountability issues and, in particular, on how the reform tends to 
significantly widen the reporting system of Italian universities, aiming at greater transparency and intelligibility of business results, and on the first Italian experiences of new forms of accountability.

\section{Methodology}

The research methodology is based on observed cases analysis and content analysis. In this way, it provides us with an interesting overview of the state-of-the-art and allows us to make some preliminary assessments about what lies behind the behaviour that universities should adopt according to the reform. To do this, we start with a brief review of the reform content and an analysis of the most relevant literature regarding the topic.

Then we try to address and to compare Italian experiences of social reporting, examining the universities involved in the social reporting process.

The methodology we have chosen is related to the reform content. In this sense, it is interesting to notice how it calls for:

- the revision of accounting rules, in order to ensure consistency with the university three-year plan, greater transparency and homogeneity, and to allow a proper evaluation of university assets and its overall management;

- the introduction of a financial and analytical accounting system and of individual and consolidated financial statements based on specific accounting principles and guidelines that will lead to the preparation of a budget and a financial accounting report, in order to allow the proper monitoring of public administrations' accounts;

- the adoption of an ethic code for the individual academic community that includes teaching and research staff, technical and administrative staff and university students. Such code will determine the fundamental values of the community, promote the acknowledgment and respect of individual rights and the acceptance of duties and responsibilities towards the institution one is part of, through its fundamental norms of conduct that are meant to be valid within the community.

\section{Reform pressures and the need for accountability in Italian universities}

Firstly, it is important to highlight that the nature of accountability is mainly public (Bovens, 2009; Ricci, 2016; Kluvers, 2003). Therefore, it is its very nature that has made this notion so important within the overall reform of the university system (Veugelers \& Van Der Ploeg, 2008). Accountability systems - aimed at rendering account by those who administer to those who are administered - originated from the dynamic of democracy (Borowiak, 2011) and responsibility and refer to the right/duty to inform that develops in companies where public money is used, regardless of the complexity and indefinability of their form and content (Sinclair, 1995, p. 224) or of their intrinsic limits (Messner, 2009, p. 924; Roberts, 2009, pp. 968-969). There has been recently much debate around the notions of autonomy and durability in Italian universities despite, or because of, a prolonged political and social delegitimation process whose main result is that public confidence in the Italian university system and its members has been at rock bottom for a while. A wide range of political, journalistic but also scientific literature, containing strong arguments and in some cases sterile criticism, is part of a process that has helped erode the Italian university system in its very foundations (Abruzzese, De Michelis \& Galli della Loggia, 1997; Morcellini \& Martino, 2005; Perotti, 2008; Simone, 1993).

The main charges and consequent verdicts regard the rating of the Italian university system, which many depict as a negative 'triple-A' (Ricci, 2013):

- Anarchia (anarchy, instead of autonomy).

- Autoreferenzialità (excessive self-reliance and isolation, especially from a scientific point of view).

- Autoconservazione (self-preservation, with relation to governance).

Decreasing public resources, low productivity of the human capital, increasing the competitiveness of international markets, increasing competition among public universities and between those and private ones (particularly after the introduction of online universities), are just some of the main reasons at the basis of a renewed interest in the topic. Such phenomena, however, have been perceived as real threats, dangerous for the whole country and for the very survival of universities in Italy, rather than as important opportunities, this way putting at risk budget autonomy and business continuity in a very short time. 
As a result of this complex phenomenology, we can say that the following intertwined factors are back on the agenda of university systems (Ricci, 2013):

- academic reputation;

- inter-institutional cooperation;

- the role of intangibles.

The awareness that the development of knowledge transmission boosts the economy and improves the nation's material and immaterial well-being, helps us to understand the legislator's choice. Academic reputation is a direct consequence of a very large set of elements not easily measurable, or measurable in an arbitrary/excessively discretionary way (Aghion, Dewatripont, Hoxby, Mas-Colell, \& Sapir, 2010, p. 14; Censis, 2009, 2010, 2011, 2012, 2013, 2014, 2015). There is currently no definition agreed upon, but it is nonetheless possible to relate its meaning to three specific key features:

a) individual and collective perception;

b) tradition and continuity over time;

c) the surrounding economic, civic and cultural context.

The academic reputation of a university therefore results from:

- what it produces in terms of research and education, and provides in terms of real services to the reference community;

- how that is perceived, either directly by the users or indirectly by the subjects that inevitably come into contact with the 'producer' or the 'product';

- the ability to maintain this perception intact over time and to continue its activity under ever-changing environmental conditions (either economic, financial, cultural, social or political ones).

Despite the complexity and uncertainty involved in any possible measurement, international rankings are mainly built according to the following parameters: quality of research, graduates' employment rate, amount of resources devoted to teaching, commitment to internationalization, assessments operated by reputable opinion leaders, but also the number of scholars or students who have been awarded the Nobel Prize or the amount of private finance attracted. Of course there are still very important methodological differences behind different rankings, and therefore equally important consequences on the scores attributed to individual universities and their reputation, with obvious legitimacy damage.

Inter-institutional cooperation, apparently a direct consequence of academic reputation, stems from the web of relations the university interweaves with the territory it is part of, often regardless of what is produced in terms of education and research. This form of cooperation is expressed and appreciated also through the consensus that the university enjoys within its reference community. Often it is sufficient to be successful (and sometimes even partially) in just one of the criteria adopted by international or national ranking committees to enjoy consensus and appreciation, to feel empowered to act and to play a significant role within the reference context. Inter-institutional cooperation is of course boosted by a good academic reputation, but in theory it can also take place when such reputation is not very high or when the elements that shape the relationship with the territory make the university itself play a different role, that is economically and socially relevant and able to guarantee wealth, autonomy and durability. The federal reform will inevitably affect the ability of universities to cooperate, not only by rationalizing the course offer or the services provided to students, but also by making academically excellent facilities more accessible to the public. The phenomenon should be more evident, for example, in those universities that were created to decongest metropolitan universities or to facilitate public cultural investments in depressed or less developed areas of the country. Such 'proximity' universities can also be described as having a 'territorial vocation'. One should not be frightened by this new presence within the Italian university system: for instance, there are currently around 2000 academic entities in the US, with five different types of universities (Carnegie Foundation 2005). Among those, only research and doctoral universities are comparable to their Italian counterparts (Carnegie Foundation for the Advancement of Teaching, 2005; Gornitzka, Kogan, Amaral, 2005).

The role of intangibles has also grown considerably in the economics of knowledge. As its main product is knowledge, a university mainly produces intangibles, and through their production and accessibility it provides the conditions for the development and growth of an economy, and those for the civilization of a territory and a population. On top of that, there is the fundamental relationship between human capital and democracy: the latter cannot work without the 
former. At the basis of democracy, there is culture, especially the humanities and a community's civilization. Social reporting in terms of intangibles, that include human, relational and social capital, is again particularly complex and problematic (GBS, 2008b; Gorz, 2003; GRI, 2002, 2006; Putnam, 2001).

The three factors mentioned above all need specific reporting tools that are able to relate in an ethically responsible and credible way the producer (university) with its stakeholders (students, professors, families, the scientific community, local bodies and institutions, businesses, financial operators etc.), that are themselves called to co-produce and co-create value. All three factors considered need appropriate forms of accountability, aimed at the best possible measurement and reporting.

Financial reporting is, therefore, insufficient, limited and even misleading when it comes to measuring research quality, the impact of education on employment, or social and civic progress: social or sustainability reporting becomes, therefore, indispensable, something that goes beyond mere financial reporting, widens the original perspective and is able to adequately support assessments on reputation and consensus (Brennan, 2011; Saves, 2000), on strategies of cooperation and inter-institutional collaboration, on choices regarding intangible assets. It is paramount to revise standard reporting procedures with relation to the three points mentioned above, and in particular to introduce models of social reporting, also seen as a tool to improve relations aimed at:

a) correctly identifying all stakeholders (Freeman, 1984);

b) clearly defining the interests at stake, not only individual but also collective ones;

c) properly defining areas of intervention;

d) measuring effects, social setbacks, outcomes, democratic sustainability, all in terms of the individual and public value generated (Moore, 1995)

\section{State of the art of the Italian academic system}

The introduction of social reporting in Italy has followed different approaches, some of them now quite well-established, while others are still at an embryonic stage. The Italian literature on the topic is quite wide (Cassone \& Zaccarella, 2009; Del Sordo, Pazzi \& Siboni, 2010; Frey, 2009; Mion \& Melchiori, 2011), contrary to what happens in the rest of the world, where the specific literature on the adoption of social accounting in universities is still patchy or scarce (Fonseca, Macdonald, Dandy, \& Valenti, 2011; Musyarofah, 2011). We can argue that there are several elements that have facilitated the introduction of social reporting in Italy (Ricci \& Civitillo, 2016):

1) cultural sensitivity and strong political will existing inside individual universities;

2) the presence of research groups directly involved in the study of ethics or accountability issues;

3) regulatory interventions promoted by reputable professionals or by the academic world, which have not directly affected the university system, but have nonetheless addressed the issue through the publication of papers, standards, guidelines, accounting principles.

Examples regarding such principles are the standards issued since 2001 by various public and private bodies, especially from the public sector: the Milan-based GBS Study Group for social reporting, with its reporting standards for the public sector, issued in 2005, and its document no. 7, regarding social reporting in universities (GBS, 2008a); the Government Directive with guidelines for social reporting, issued in 2006; the Observatory for finance and accounting in local administrations at the Ministry of the Interior, with its guidelines for social reporting, issued in 2007. A study carried out in February 2016 and covering all Italian public universities, allowed us to assess the current situation in relation to social reporting. The methodology adopted was that of the telephone interview following examination of university websites and official published documents. The first social report is dated 2004, referring to the period 2002/2003.

No doubt all content must be checked case by case. However, it is worth stressing that almost all universities declare to refer to a specific standard or guideline. Table 1 indicates the cases considered. 
Paolo Ricci, Renato Civitillo

The Culture of Accountability in Italian Universities: Strengths and Weaknesses

Table 1: Social reporting in Italian universities (general overview)

\begin{tabular}{|c|c|c|c|c|c|}
\hline$n$. & University & $\begin{array}{c}\text { First } \\
\text { social } \\
\text { report } \\
\text { (year) }\end{array}$ & $\begin{array}{c}\text { Number of } \\
\text { reports so } \\
\text { far }\end{array}$ & Methodology adopted & Time span \\
\hline 1 & $\begin{array}{l}\text { Università degli Studi di BARI ALDO } \\
\text { MORO }\end{array}$ & 2006 & 2 & $\begin{array}{l}\text { GBS (ecceptions listed in the methodology } \\
\text { note) }\end{array}$ & Triennial \\
\hline 2 & Università degli Studi di BOLOGNA & 2012 & 3 & GBS; Baccini Directive; GRI & Annual \\
\hline 4 & Università degli Studi di FERRARA & 2006 & 8 & Baccini Directive; GRI & Annual/Biennial \\
\hline 5 & Università degli Studi di FIRENZE & 2006 & 1 & GBS; Baccini Directive; GRI & Annual \\
\hline 6 & Università degli Studi di GENOVA & 2010 & 1 & No specific methodology adopted & Triennial \\
\hline 7 & $\begin{array}{l}\text { Università degli Studi INSUBRIA } \\
\text { Varese-Como }\end{array}$ & 2007 & 1 & GBS; Baccini Directive; GRI & Annual \\
\hline 11 & Università di PISA & 2013 & 1 & GBS; Baccini Directive; GRI; AA 1000 & Quadriennial \\
\hline 12 & $\begin{array}{l}\text { Scuola Sup. di Studi Univ. e Perf. } \\
\text { S.Anna di PISA }\end{array}$ & 2004 & 2 & GRI; ABI Guidelines; GBS & Biennial \\
\hline 13 & Università degli Studi del SALENTO & 2012 & 1 & GBS & Biennial \\
\hline 14 & Università degli Studi di SALERNO & 2011 & 3 & GBS; Baccini Directive & Triennial \\
\hline 15 & $\begin{array}{l}\text { Università degli Studi del SANNIO di } \\
\text { BENEVENTO }\end{array}$ & 2006 & 4 & GBS & Biennial \\
\hline 16 & Università degli Studi di TRIESTE & 2008 & 2 & GBS & Annual \\
\hline
\end{tabular}

Source: Our elaboration, 2016

Table 2: Social reporting in Italian universities (based on number of reports so far)

\begin{tabular}{|c|c|}
\hline Italian State Universities & 67 \\
\hline Universities with at least one social report & 16 \\
\hline $\begin{array}{l}\text { Universities that have never prepared a } \\
\text { social report }\end{array}$ & 51 \\
\hline
\end{tabular}

Source: Our elaboration, 2016

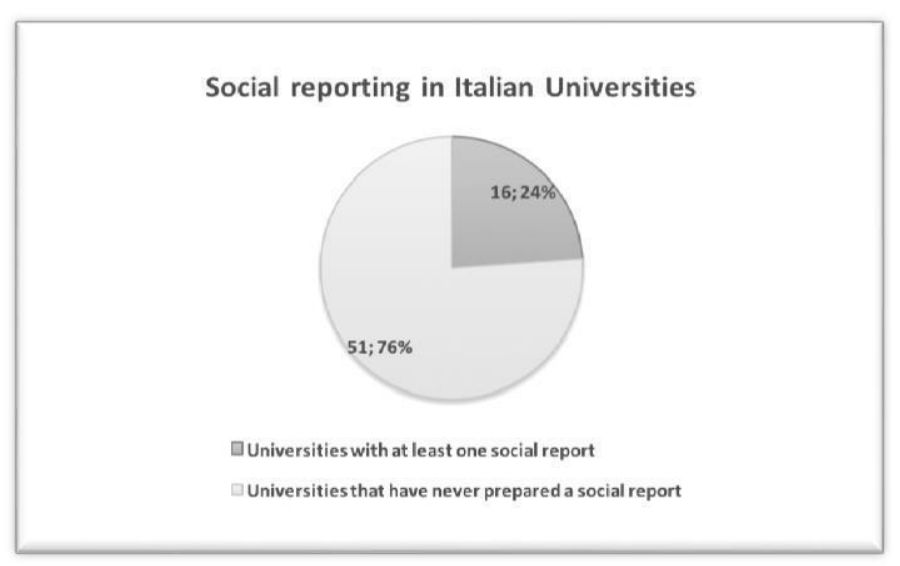

Figure 1: Social reporting in Italian universities (based on number of reports so far)

Source: Our elaboration, 2016

Table 2 and Figure 1 shows the overall picture, with a substantial $76 \%$ of Italian universities that still does not prepare any social or sustainability report. Figure 2 provides some indications regarding if and how sensitivity to the topic investigated changes according to where the university is based. It is quite clear that in terms of social accountability there is not a 'southern problem', unlike what has been said for centuries with relation to economy, development and 
quality of life. As to the methodologies adopted, the picture is on the other hand quite varied, with standards, guidelines and recommendations being similarly used. The GBS standard is currently preeminent, for different reasons: a) it is an Italian standard; b) it is university-specific; c) it is modelled on content and therefore more useful.

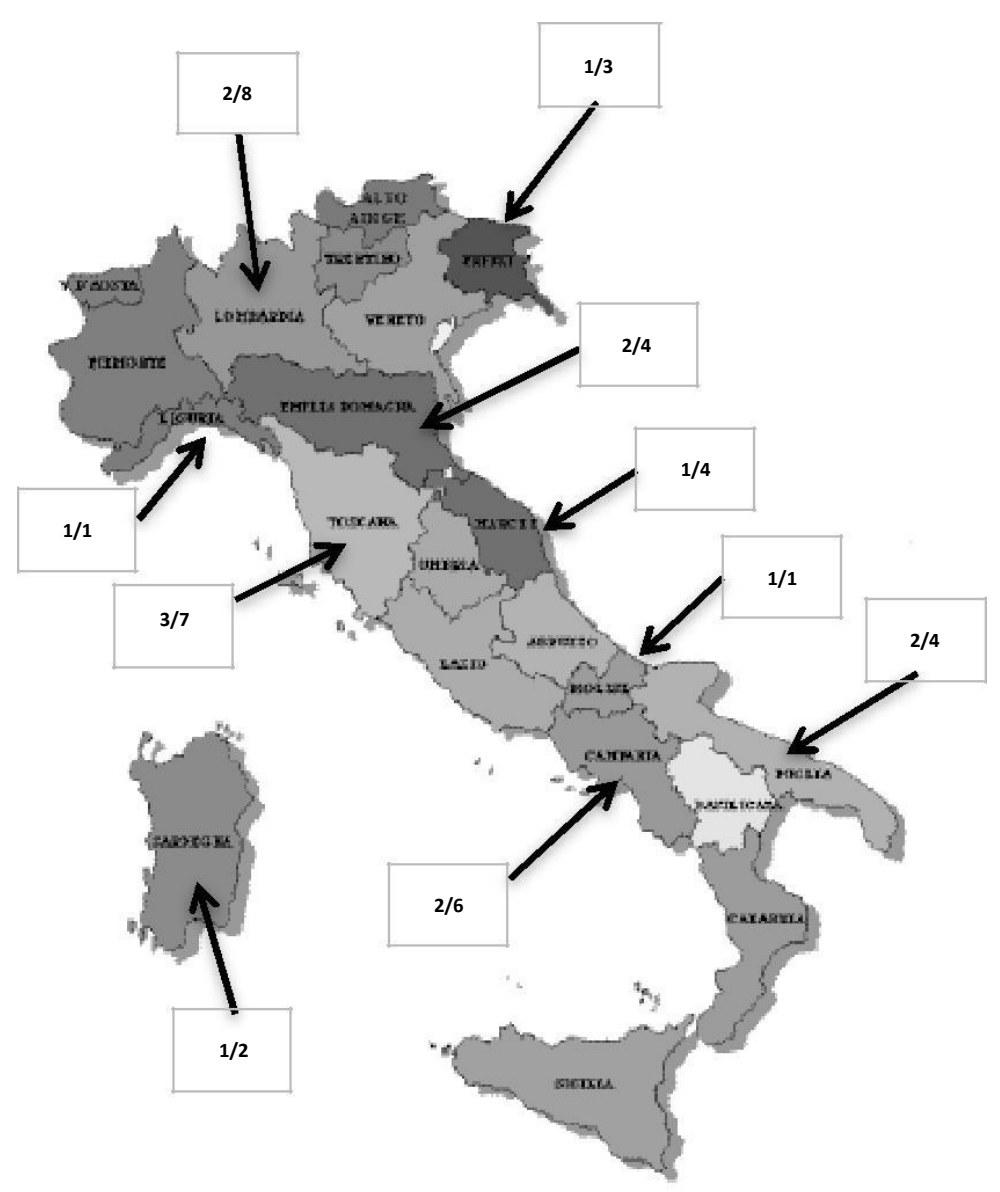

Figure 2: Geographical distribution of Italian universities adopting social reporting systems Source: Our elaboration, 2016

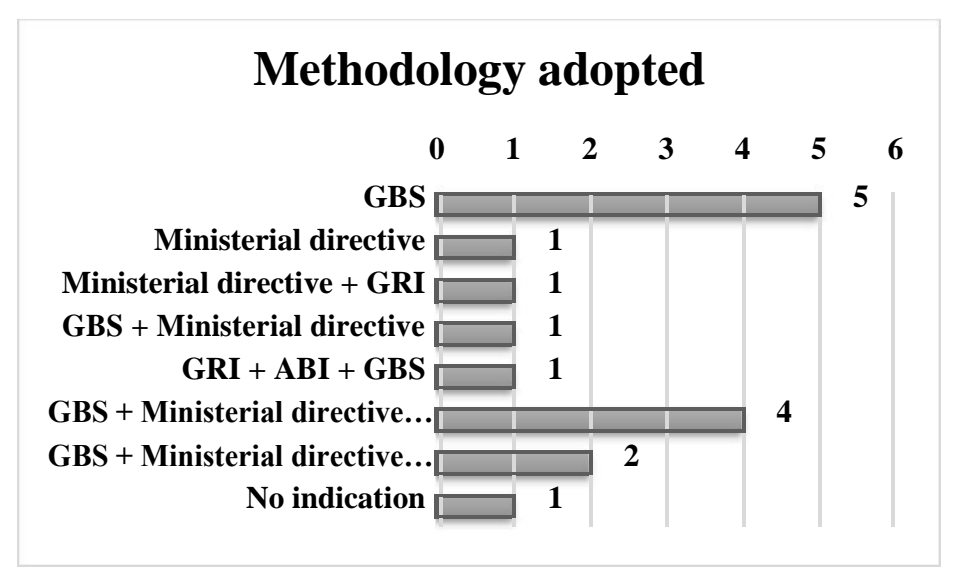

Figure 3: Methodologies adopted by Italian universities with relation to social reporting Source: Our elaboration, 2016 


\section{Conclusion}

Despite of what we stated previously many reflections are still required. In fact, as highlighted in our previous study (Ricci, 2013; Ricci \& Civitillo, 2016) because of the opacity of public budgets and other traditional tools of public reporting, much elaborations are necessary. First, the balance sheet should be considered as a true 'window for values'. Second, financial statements and synthetic accounting records cannot automatically make clear and understandable what is not always so: as we noted earlier, many evaluations require very complex non-financial measurements, not always concisely expressible through monetary indicators. Social reporting can, therefore, play an important role in the academic world. Based on the principles of consistency, transparency, clarity and usefulness of information, it can facilitate the full understanding of economic, political and social phenomena, therefore making academic strategies and policies easier to understand, to share and especially to finance and support if worthy. In recent years it has become clear that the legitimacy of the public administration towards society is not based solely on its institutional nature, but more and more on its ability to provide goods and services in a way that perfectly matches the expectations of citizens, workers, families and of the market in general (Pollitt, 1993; Pollitt \& Bouckeart, 2000). This new relational configuration is also valid, albeit still not clearly appreciated, for the academic system, especially the Italian one in which private universities are scarce and financial autonomy is still very modest. Being early days, what said above inevitably involves some risks: the first one is to use initial forms of social reporting tools as 'safe havens' (for generic and ineffective models of administrative responsibility) rather than as 'uncertain starting points' (for effective and specific models of administrative responsibility).

This means that the lack or the absence of generally accepted models and standards, restricts the usefulness and the true meaning of social reporting arising. In particular, two are the main limitations:

a) excessive self-reliance;

b) reluctant comparison, are still considerable.

In scientific literature, the term accountability refers to the duty by an individual to be accountable towards others for his/her actions to define the relations between planning, decision, action and control in responsible and credible fashion (Ricci, 2005, p. 13). More specifically, it is necessary to report how economic and financial resources were used, the transparency employed by people involved in the management, compliance with targets set at planning stage and with social results achieved over time, all that ensuring impartiality and comparability. The conditions under which such compliance is evaluated depend on how good the academic system of accountability really is.

In this way, we can say that the definition of a degree of accountability depends on the following key factors (Ricci, 2005, p. 14):

- clear planning process;

- clear definition of internal and external responsibilities;

- adequate accounting and extra accounting record systems;

- effective internal monitoring and evaluation system;

- periodic reporting on the activities performed;

- significant benchmarking activity;

- significant use of technology in running communication processes.

The presence of such factors positively affects evaluation and accountability processes. Along these lines, social reporting should also improve the way third parties can evaluate the activities performed, in order to enhance managerial awareness. Reporting therefore has got an even deeper meaning and role in universities, if we think about the fact that resources come from direct and indirect contributions by local communities - this being the way the current system actually works - and that the money used is public, i.e. comes from the exercise of public functions but most important its use is aimed at promoting competitiveness, progress, democracy. This requires clear and thorough reporting, and strengthens the belief that only a legal obligation can ensure, at least at the beginning, the introduction and development of appropriate accountability systems in public bodies. In this regard the university reform, as per law 240/2010, should have been bolder.

Goal factors may be summarized as follows (Ricci, 2013, pp. 218-219):

- to spread the institution's reputation;

- to improve the management of consensus and of social legitimacy;

- to avoid boycott of the services provided; 
- to face and overcome crises;

- to allow public debate regarding strategic choices to be made;

- to better focus on the results achieved;

to make decisions that take better into account tax issues;

to facilitate internal (among departments) and external (among universities) comparison;

to facilitate inter-institutional cooperation in federal perspective;

to compete in the distribution of bonuses or rewards.

Effective accountability systems can indeed turn from tools into goals in public administrations, and in doing so reporting takes on a completely different meaning: it is a contribution to the social added value created by the university, an extra obligation to take towards stakeholders, a further service to engage in to strengthen democracy. It is, therefore, clear that the culture of accountability should be introduced and guided mainly by law, with legal requirements about deadlines, tools and goals, and supervised by third-party authorities. Specific agencies should therefore be set up during government mandates, in order to assess accuracy and transparency of the information provided, and take steps in cases of manipulation or misuse of investments in disclosure and accountability. The definition of social reporting principles, recommendations or guidelines takes on a specific meaning in public administrations in general, and in universities in particular. In this sense, the mandatory adoption of social reporting or, if that is still performed on a voluntary basis, a clearer indication of principles or rules about processes or content, may represent one of the potential strategies to be undertaken.

\section{References}

- Abruzzese, A., De Michelis, C., \& Galli della Loggia, E. (1997). Sostiene Berlinguer. Venezia: Marsilio.

- Aghion, P., Dewatripont M., Hoxby, C.M., Mas-Colell, A., \& Sapir, A., (2010). The governance and performance of universities: evidence from Europe and the US. Economic Policy, 25(6), 7-59, CrossRef

- Angluin, D., \& Scapens, R.W. (2000). Transparency, Accounting Knowledge and perceived fairness in UK universities' resource allocation: results from survey of accounting and finance. British Accounting Review, 32, 1-42, CrossRef

- Borowiak, C. T. (2011). Accountability and democracy. The pitfalls and promise of popular control. Oxford: Oxford University Press, CrossRef

- Bovens, M. (2009). Public Accountability. In E. Ferlie, L. E Lynn Jr., \& C. Pollitt (Eds.). The Oxford Handbook of Public Management. Oxford: Oxford University Press.

- Brennan, J. (2011). The ethics of voting. Princeton: Princeton University Press, CrossRef

- Carnegie Foundation for the Advancement of Teaching. (2005). Carnegie Classification of Instituitions of Higher Education. Retrieved from http://www.carnagiefoundation.org/classifications/

- Cassone, A., \& Zaccarella, P. (2009). Il bilancio sociale delle università. Inventario dei problemi e analisi comparata delle esperienze italiane. Working Paper n. 130, Novara: Università del Piemonte Orientale.

- Catalano, G., (2009). La contabilità economico-patrimoniale nelle università. Bologna: Il Mulino.

- Censis - La Repubblica. (2009). Classifiche Atenei Italiani. Retrieved from http://temi.repubblica.it/guideuniversita2009/

- Censis - La Repubblica. (2010). Classifiche Atenei Italiani. Retrieved from http://temi.repubblica.it/guideuniversita2010/

- Censis - La Repubblica. (2011). Classifiche Atenei Italiani. Retrieved from http://www.censismaster.it/document/it/classifica_2011_degi_atenei_statali/primo_piano

- Censis - La Repubblica. (2012). Classifiche Atenei Italiani. Retrieved from http://www.censismaster.it/ViewDocument.aspx?lang=it\&docid=4935894154a44e77987cef820eecfe01

- Censis - La Repubblica. (2013). Classifiche Atenei Italiani. Retrieved from http://www.censismaster.it/document/it/La_classifica_Censis_degli_Atenei_2013-2014/new

- Censis - La Repubblica. (2014). Classifiche Atenei Italiani. Retrieved from http://www.censismaster.it/document/it/Classifica_Universita_2014-2015_targata_Censis/primo_piano\#

- Censis - La Repubblica. (2015). Classifiche Atenei Italiani. Retrieved from http://www.censismaster.it/ViewDocument.aspx?lang=it\&docid=48dc85768b6d4e07b652f99070d17b17

- Deem, R. (2003). Gender, Organizational Cultures and the Practices of Manager-Academics in UK Universities. Gender, Work and Organization, 19 (2), 239-259, CrossRef 
- Del Sordo, C., Pazzi, S., \& Siboni, B. (2010). La rendicontazione sociale nelle Università: una lettura critica. Non profit, 3, 69-101.

- Fonseca, A., Macdonald, A., Dandy, E., \& Valenti, P. (2011). The state of sustainability reporting at Canadian universities. International Journal of Sustainability in Higher Education, 12(1), 22-40, CrossRef

- Freeman, E. R. (1984). Strategic Management: A stakeholder Approach. Marshfield, MA: Pitman.

- Frey, M. (2009). Il bilancio sociale delle università. Impresa Progetto, 1, 1-14.

- GBS, Gruppo di studio Bilancio Sociale. (2008a). Documenti di ricerca n. 7, La rendicontazione sociale nelle università. Milano: Giuffrè.

- GBS, Gruppo di studio Bilancio Sociale. (2008b). Documenti di ricerca n. 8, La rendicontazione sociale degli intangibili. Milano: Giuffrè.

- Gornitzka, A., Kogan, M., \& Amaral, A. (2005). Reform and change in higher education, Berlin: Springer, CrossRef

- Gorz, A. (2003). L'immatériel. Connaissance, valeur et capital. Paris: Editions Galilée.

- Gray, R. (2002). The social accounting project and accounting organizations and society. Privileging engagement, imaginings, new accountings and pragmatism over critique?. Accounting, Organizations and Society, 27(7), 687-708.

- Gray, R., Owen, D.L., \& Adams, C. (1996). Accounting and Accountability: Social and environmental accounting in a changing world. Hemel Hempstead: Prentice Hall, $\underline{\text { CrossRef }}$

- GRI-Global Reporting Initiative. (2002). Sustainability Reporting Guidelines. Boston: GRI.

- GRI-Global Reporting Initiative. (2006). Sustainability Reporting Guidelines. Boston: GRI.

- Kluvers, R. (2003). Accountability for Performance in Local Government, Research \& Evaluation. Australian

- Journal of Public Administration, 62(1), 57-69, CrossRef

- Messner, M. (2009). The limits of accountability. Accounting, Organizations and Society, 34(8), 918-938, CrossRef

- Mion, G., \& Melchiori, M. (2011). Il processo di redazione del bilancio sociale negli Atenei pubblici come fattore strategico per una comunicazione attendibile. Economia Aziendale On Line, 1, 117-129.

- Moore, M.H. (1995). Creating public value. Strategic management in government, Cambridge: Harvard University Press.

- Morcellini, M., \& Martino V. (2005). Contro il decline dell'università. Milano: Il Sole24Ore.

- Mulgan, R. (2000). Accountability: An ever-expanding concept?. Public Administration, 78(3), 555-573, CrossRef

- Musyarofah, S. (2011). The need for sustainability based accounting education (Case study in Indonesia's Higher Education). Working Paper. Retrieved from http://www.wbiconpro.com/106-Siti.pdf

- Perotti, R. (2008). L'università truccata. Torino: Einaudi.

- Pezzani, F. (2003). L'accountability delle amministrazioni pubbliche. Milano: Egea.

- Pollitt, C. (1993). Managerialism and Public Services, The Anglo-American Experience. Oxford: Blackwell.

- Pollitt, C., \& Bouckeart, G. (2000). Public Management Reform: a comparative analysis. New York: Oxford University Press, CrossRef

- Putnam, R. (2001). Bowling Alone: The Collapse and Revival of American Community. New York: Simon \& Schuster.

- Ricci, P. (2005). Enti strumentali regionali e loro accountability. Il caso Campania. Milano: Franco Angeli.

- Ricci, P. (2013). What future for social reporting and accountability in academic systems. An overview of the Italian case. Review of International Comparative Management, Academy of Economic Studies Bucharest, 14(2), 202-221.

- Ricci, P. \& Civitillo, R. (2016). Social reporting and accountability in Italian academic systems, in Smart and Efficient Economy: Preparation for the Future Innovative Economy - 21 th International Scientific Conference - Proceeding of Selected Papers, Brno University of Technology, Faculty of Business and Management, 463 471.

- Roberts, J. (2009). No one is perfect: The limits of transparency and the ethic for "intelligent" accountability. Accounting, Organizations and Society, 34, 957-970, $\underline{\text { CrossRef }}$

- Saves, S. (2000). Privatization and Public-Private Partnership. New York: Chatham House Publishers.

- Simone, R. (1993). L'università dei tre tradimenti. Roma: Laterza. 
- Sinclair, A. (1995). The chameleon of accountability: Forms and discourses. Accounting, Organizations and Society, 20(2-3), 219-237, CrossRef

- Stoker, J. (1998). Governance as theory: five propositions. UNESCO: Blackwell Publishers.

- Veugelers, F., \& Van Der Ploeg, R. (2008). Towards Evidence-based Reform of European Universities. Oxford: Oxford University Press.

- Watzlawick, P., Weakland, J.H., \& Fisch, R. (1973). Change, Principles of problem formation and problem solution. Palo Alto: Mental Research Institute Palo Alto. 